\title{
ANALISIS PENGGUNAAN ECONOMIC VALUE ADDED (EVA) SEBAGAI ALAT UKUR KINERJA KEUANGAN PADA PT. GUDANG GARAM, TBK YANG TERCATAT DI BURSA EFEK INDONESIA
}

\author{
Oleh: \\ Wati Silitonga \\ S1 Akuntansi \\ Pinondang Nainggolan, Parman Tarigan, Ady Inrawan
}

Abstraksi

Tujuan penelitian ini adalah Untuk mengetahui Kinerja Keuangan PT. Gudang Garam, Tbk bila diukur dengan Economic Value Added (EVA). Penelitian dilakukan menggunakan data sekunder dari laporan keuangan perusahaan yang diperoleh dari website http://www.idx.co.id dan sumber-sumber lainnya. Metode yang digunakan dalam penelitian ini adalah Analisis Deskriptif Kualitatif dan Analisis komparatif.

Hasil penelitian dapat disimpulkan sebagai berikut: EVA tahun 2009-2014 menunjukkan bahwa manajemen perusahaan belum mampu menciptakan nilai EVA yang positif yang artinya perusahaan belum dapat menciptakan nilai tambah kekayaan perusahaan. Hal ini disebabkan karena biaya modal lebih tinggi dari pada NOPAT sehingga nilai EVA negatif, maka dapat dikatakan kinerja perusahaan tersebut buruk. Dalam meningkatkan EVA, sebaiknya perusahaan mengurangi penggunaan biaya modal dengan mengurangi pinjaman (hutang). Dalam pengaplikasian EVA sebaiknya pihak managemen memonitori atau mengevaluasi atas kewajaran tingkat biaya modal yang digunakan dalam sebuah operasi usaha.

Kata kunci: Economic Value Added (EVA) dan Kinerja Keuangan

\section{Abstraction}

The purpose of this research is to know the Financial Performance of PT. Gudang Garam Tbk when measured by Economic Value Added (EVA). The research was conducted using secondary data from company financial reports which obtained from the website http://www.idx.co.id and other sources. The method used in this research is qualitative descriptive analysis and comparative analysis.

The results of the study can be summarized as follows: EVA for 2009-2014 show that the management company has not been able to create positive EVA which means that the company has not been able to create added value for the company's assets. This is because the cost of capital is higher than the value of EVA NOPAT so that negative, it can be said the company has poor performance. In improving EVA, the company should reduce the use of capital by reducing the cost of debt and In the application of EVA management should monitor and evaluate the fairness of the level of capital costs that are used in a business operation.

Keywords: Economic Value Added (EVA) and Financial Performance

\section{A. PENDAhuluan}

1. Latar Belakang Masalah

Setiap lembaga atau perusahaan harus memperhatikan kesehatan keuangannya, sehingga tidak merugikan pihak lain, baik pemerintah maupun lembaga atau perusahaan itu sendiri. Kinerja suatu perusahaan dapat digunakan untuk mengukur keberhasilan suatu perusahaan. Fungsi pengukuran kinerja adalah sebagai alat bantu bagi manajemen perusahaan dalam proses pengambilan keputusan dan juga untuk memperlihatkan kepada investor maupun pelanggan atau masyarakat umum bahwa perusahaan mempunyai kredibilitas yang baik. Apabila perusahaan mempunyai kredibilitas yang baik, hal itu akan mendorong investor untuk menanamkan modalnya pada perusahaan tersebut.

Untuk mengetahui kemampuan perusahaan dalam mengelola modal yang disetor investor, diperlukan adanya pengukuran terhadap kinerja perusahaan. Pada umumnya perusahaan yang mempunyai kinerja bagus akan mempunyai prospek kenaikan harga saham dengan cepat. Salah satu alat yang digunakan untuk mengukur kinerja perusahaan adalah analisis rasio keuangan. Namun, analisis rasio mempunyai beberapa kelemahan. Kelemahan utamanya adalah bahwa analisis rasio belum memperhatikan adanya biaya modal, sehingga penilaian kinerja tersebut belum sempurna. Mengingat keterbatasan analisis rasio sebagai alat pengukur kinerja keuangan, dilakukan pendekatan konsep baru yaitu disebut Economic Value Added (EVA).

Konsep EVA merupakan suatu konsep penilaian kinerja keuangan perusahaan yang dikembangkan oleh Stern Stewart \& Co, Sebuah perusahaan konsultan manajemen keuangan di Amerika Serikat (Anthony dan Vijay, 2005:335). Konsep EVA membuat perusahaan lebih memfokuskan perhatian ke upaya penciptaan nilai perusahaan dan menilai kinerja keuangan perusahaan secara adil yang diukur dengan menggunakan ukuran tertimbang (weighted) dari struktur modal yang ada. Perhitungan EVA diharapkan dapat memperoleh hasil perhitungan pada upaya penciptaan kinerja perusahaan yang lebih realistis. EVA memfokuskan penilaian pada nilai tambah dengan 
memperhitungkan beban biaya modal sebagai konsekuensi investasi.

\section{Rumusan Masalah}

Berdasarkan latar belakang masalah di atas, maka rumusan masalah dalam penelitian ini adalah: Bagaimana Kinerja Keuangan PT. Gudang Garam, Tbk bila diukur dengan Economic Value Added (EVA)?

\section{Tujuan Penelitian}

Berdasarkan rumusan masalah di atas, maka dapat dijelaskan bahwa tujuan penelitian ini adalah: Untuk mengetahui Kinerja Keuangan PT. Gudang Garam, Tbk bila diukur dengan Economic Value Added (EVA).

\section{Metode Penelitian}

Dalam penelitian ini, penulis mengambil objek penelitian pada PT. Gudang Garam, Tbk yang tercatat di Bursa Efek Indonesia, Jl. Semampir ll No. 1 Kediri 64121 Jawa Timur, Indonesia. Namun untuk memperoleh data yang dibutuhkan penulis mengakses data melalui website http://www.idx.co.id.

Adapun Desain penelitian yang digunakan dalam penulisan penelitian ini adalah Penelitian Kepustakaan (Library Research). Teknik pengumpulan data yang dilakukan penulis dalam penelitian ini adalah dokumentasi. Adapun jenis data yang digunakan dalam penelitian ini adalah jenis data kualitatif dan data kuantitatif. Teknik analisis data yang digunakan dalam penelitian ini terdiri dari analisis deskriptif kualitatif dan analisis komparatif.

\section{B. LANDASAN TEORI}

1. Laporan Keuangan

Menurut Baridwan (2004:17), laporan keuangan merupakan ringkasan dari suatu proses pencatatan dari transaksi-transaksi keuangan yang terjadi selama tahun buku yang bersangkutan. Penyajian laporan keuangan menyatakan bahwa laporan keuangan lengkap terdiri dari beberapa jenis yaitu (Martani, dkk, 2012:10):

a. Laporan posisi keuangan (Neraca) merupakan daftar sistematis dari asset, utang dan modal pada tanggal tertentu, yang biasanya dibuat pada akhir tahun.

b. Laporan laba rugi komprehensif adalah ikhtisar mengenai pendapatan dan beban suatu entitas untuk periode waktu tertentu, sehingga dapat diketahui laba yang diperoleh dan rugi yang dialami.

c. Laporan arus kas

Dengan adanya laporan ini, pemakai laporan keuangan dapat mengevaluasi perubahan asset neto entitas, struktur keuangan (termasuk likuiditas dan solvabilitas) dan kemampuan entitas menghasilkan kas di masa mendatang.

d. Laporan perubahan ekuitas adalah laporan yang menunjukkan perubahan ekuitas pada periode tertentu, bisa satu bulan atau satu tahun. e. Catatan atas laporan keuangan merupakan laporan yang berisi informasi tambahan atas apa yang disajikan dalam empat laporan di atas.

\section{Economic Value Added (EVA)}

Economic Value Added (EVA) merupakan pengukuran kinerja bisnis sejenis laba ekonomis, nilainya sama dengan laba setelah pajak dikurangi nilai pembebanan modal (ditambah beberapa penyesuaian) (Horne dan John, 2013:106). Cara lain untuk menjelaskan fakta bahwa untuk menciptakan nilai, perusahaan harus mendapatkan imbal hasil atas modal yang diinvestasikan lebih besar dari biaya modalnya, melalui konsep EVA.

Menurut Brigham dan Joel (2006:124) rumus EVA yaitu:

$\mathrm{EVA}=\mathrm{EBIT}(1-\mathrm{T})-\mathrm{WACC}(\mathrm{IC})$

Keterangan :

$$
\begin{array}{llll}
\text { EBIT } & =\text { Laba Sebelum bunga dan Pajak } \\
\mathrm{T} & =\text { Tarif Pajak } \\
\text { WACC } & \text { Biaya Modal Rata-rata } \\
\text { Tertimbang } & \\
\mathrm{IC} \quad= &
\end{array}
$$

Komponen-komponen pendukung untuk memperoleh perhitungan Economic Value Added (EVA) adalah sebagai berikut (Brigham dan Joel, 2006:65):

a. NOPAT (Net Operating Profit After Tax)

NOPAT (Net Operating Profit After Tax) merupakan laba yang dihasilkan suatu perusahaan jika perusahaan tersebut tidak memiliki hutang dan hanya memiliki asset operasi (Brigham dan Joel, 2012:108).

NOPAT dinyatakan sebagai berikut NOPAT $=$ EBIT $(1-T)$

Keterangan :

$$
\begin{array}{ll}
\text { NOPAT } & \text { Laba Setelah Pajak } \\
\mathrm{T} & =\text { Tarif Pajak } \\
\text { EBIT } & =\text { Laba Sebelum Bunga dan } \\
\text { Pajak } &
\end{array}
$$

b. WACC (Weight Average Cost Of Capital)

Menurut Brigham dan Joel (2011:7), Weight Average Cost Of Capital(WACC) adalah hasil penjumlahan dari hasil perkalian besarnya proporsi masing-masing jenis modal dengan biaya modal yang bersangkutan.

WACC dapat dihitung dengan rumus sebagai berikut (Brigham dan Joel, 2011:7):

$\mathrm{WACC}=\mathrm{Wd} . \mathrm{Kd}(1-\mathrm{T})+\mathrm{Ws} . \mathrm{k}$

Keterangan :

$\begin{array}{ll}\text { WACC } & =\text { Biaya Modal Rata-rata } \\ \text { Tertimbang } & \\ \mathrm{T} & =\text { Tarif Pajak } \\ \mathrm{Wd} & =\text { Proporsi Sasaran Utang } \\ \mathrm{Kd} & =\text { Biaya Utang } \\ \mathrm{Ws} & =\text { Proporsi Ekuitas Biasa } \\ \mathrm{Ks} & =\text { Biaya Ekuitas }\end{array}$

c. Invested Capital/Modal yang diinvestasikan Modal yang di investasikan sama dengan jumlah ekuitas pemegang saham dan kewajiban jangka panjang. Menurut Young dan O'Byrne (2009:23), Invested Capital dapat dihitung sebagai berikut: 
Invested Capital $=$ Total kewajiban + Ekuitas pemegang saham

\section{Kinerja Keuangan}

Menurut Jumingan (2006:239), kinerja keuangan adalah gambaran kondisi keuangan perusahaan pada suatu periode tertentu baik menyangkut aspek penghimpunan dana maupun penyaluran dana, yang biasanya diukur dengan indikator kecukupan modal, likuiditas, dan profitabilitas. Sedangkan menurut Munawir (2002:50), kinerja keuangan adalah kemampuan dari suatu perusahaan dalam menggunakan modal yang dimiliki secara efektif dan efisien guna mendapatkan hasil yang maksimal.

Dari definisi yang dipaparkan di atas dapat ditarik suatu kesimpulan bahwa kinerja keuangan adalah gambaran kondisi keuangan perusahaan dalam menggunakan modal yang dimiliki secara efektif dan efisien yang biasanya diukur dengan indikator kecukupan modal, likuiditas, dan profitabilitas untuk mendapatkan hasil yang maksimal.

\section{Hubungan Economic Value Added} (EVA) dengan Kinerja Keuangan

Nilai buku Ekonomis perusahaan sama dengan jumlah total yang dikumpulkan perusahaan dari para pemegang sahamnya atau dari jumlah yang ditahan dan diinvestasikan kembali untuk kepentingan mereka (Brealey, dkk, 2007:92). Jika perusahaan berhasil menambah nilai, nilai pasar ekuitas akan lebih tinggi dari pada nilai buku.

Ukuran kinerja perusahaan berdasarkan nilai pasar mempunyai dua kelemahan. Pertama, nilai pasar saham perusahaan mencerminkan ekspektasi investor. Investor menempatkan nilai tinggi pada saham sebagian karena mereka percaya bahwa manajemennya akan terus menemukan investasi menguntungkan di masa depan. Masalahnya adalah mereka tidak memperhitungkan tentang biaya-biaya dalam mendapatkan keuntungan tersebut atau bisa dikatakan keuntungan yang sementara. Kedua, nilai pasar tidak dapat digunakan untuk menilai kinerja perusahaan yang dimiliki secara pribadi atau kinerja divisi atau pabrik yang menjadi bagian perusahaan yang lebih besar. Oleh karena itu, manajer keuangan juga menghitung ukuran kinerja perusahaan dengan menggunakan EVA.

EVA adalah ukuran kinerja perusahaan yang lebih baik dari pada laba akuntansi. Laba dihitung setelah mengurangi semua biaya. Setelah kita menghitung atau menganalisis kinerja keuangan perusahaan tersebut dengan menggunakan alat ukur EVA, maka kita akan mengetahui apakah kinerja perusahaan tersebut baik. EVA menyadari bahwa perusahaan harus menutup biaya modal mereka sebelum mereka menambah nilai. Jika sebuah perusahaan menghasilkan EVA> 0, maka pihak manajemen terutama pada divisi yang membuat EVA akan mendapatkan bonus karena sudah membuat EVA lebih dari nol dengan kata lain positif. Jika sebuah perusahaan menghasilkan EVA <
0 , artinya kinerja perusahaan tersebut kurang baik atau dapat dikatakan buruk. Kemudian jika perusahaan menghasilkan EVA $=0$, artinya ada keadaan impas dimana perusahaan tidak mengalami peningkatan maupun penurunan. Karena itu, kini semakin banyak perusahaan yang menghitung EVA (Brealey, dkk, 2007:92).

\section{PEMBAHASAN}

$$
\text { 1. Analisa }
$$

a. NOPAT (Net Operating Profit After Tax)Pada PT. Gudang Garam, Tbk yang tercatat di Bursa Efek Indonesia Periode 2009-2014

Berdasarkan hasil analisis perhitungan NOPAT, keadaan NOPAT Pada PT. Gudang Garam, Tbk yang terdaftar di Bursa Efek Indonesia periode 20092014, menunjukkan bahwa NOPAT pada tahun 2009 adalah sebesar Rp 3.476.313 dan pada tahun 2010 NOPAT mengalami peningkatan menjadi Rp 4.223.472, begitu pula di tahun 2011 NOPAT mengalami peningkatan menjadi $\mathrm{Rp}$ 4.961.228.

Pada tahun 2012 NOPAT mengalami penurunan menjadi $\mathrm{Rp}$ 4.147.985. Penurunan NOPAT ini disebabkan karena adanya penurunan EBIT. Kemudian pada tahun 2013 NOPAT mengalami peningkatan menjadi RP 4.447.985, begitu pula pada tahun 2014 dimana NOPAT mengalami peningkatan menjadi Rp 5.404.384

b. WACC (Weight Average Cost Of Capital) Pada PT. Gudang Garam, Tbk yang tercatat di Bursa Efek Indonesia Periode 2009-2014

Berdasarkan hasil analisis perhitungan WACC diperoleh bahwa WACC pada tahun 2009 sebesar $15 \%$ dan pada tahun 2010 WACC mengalami peningkatan sehingga WACC tahun 2010 menjadi $15 \%$. Pada tahun 2011 WACC mengalami penurunan menjadi $14 \%$. Pada tahun 2012 WACC juga mengalami penurunan menjadi $11 \%$. Kemudian pada tahun 2013 WACC mengalami penurunan menjadi $11 \%$, dan pada tahun 2014 WACC mengalami peningkatan menjadi $12 \%$.

Berdasarkan hasil tersebut di atas terlihat bahwa dari tahun 2009-2014 Pada PT. Gudang Garam, Tbk belum juga berhasil menurunkan biaya modal rata-rata tertimbang (WACC). Hal ini akan sangat menghalangi perusahaan untuk mendapatkan nilai EVA yang positif sehingga tidak dapat memberikan nilai tambah ekonomis bagi perusahaan.

\section{c. Invested Capital/Modal yang diinvestasikan Pada PT. Gudang Garam, Tbk yang tercatat di Bursa Efek Indonesia Periode 2009-2014}

Berdasarkan hasil analisis perhitungan IC (Invested Capital) sebesar Rp 27.149.961 dan pada tahun 2010 IC mengalami peningkatan menjadi Rp 30.618.565. Pada tahun 2011 IC mengalami peningkatan sehingga menjadi Rp 39.088.705. Pada tahun 2012 IC mengalami peningkatan menjadi Rp 41.509.325.Kemudian Pada tahun 2013 IC mengalami peningkatan menjadi Rp 50.770.251, begitu pula pada tahun 2014 IC mengalami 
peningkatan menjadi Rp 58.220.600. Berdasarkan tabel 12 kita dapat melihat bahwa total modal yang diinvestasikan dari tahun 2009-2014 terus mengalami peningkatan.

d. EVA (Economic Value Added) Pada PT. Gudang Garam, Tbk yang tercatat di Bursa Efek Indonesia Periode 2009-2014

Berdasarkan hasil analisis perhitungan diperoleh bahwa pada tahun 2009 nilai EVA sebesar minus Rp 596.181. EVA tahun 2010 mengalami penurunan menjadi minus Rp369.313 begitu juga tahun 2011 EVA mengalami penurunan menjadi minus Rp511.191. Namun pada tahun 2012 EVA mengalami peningkatan menjadi minus Rp418.041, pada tahun 2013 dan 2014 EVA mengalami penurunan yang sangat drastis, dimana EVA pada tahun 2013 menurun menjadi minus Rp1.136.743 dan pada tahun 2014 EVA juga mengalami penurunan menjadi minus Rp1.582.088.

Berdasarkan perhitungan nilai EVA dari Tahun 2009-2014 menunjukkan bahwa manajemen perusahaan belum mampu menciptakan nilai EVA yang baik, dimana nilai EVA pada tahun 2013-2014 terus menerus mengalami penurunan yang sangat tajam.

\section{Evaluasi}

a. NOPAT (Net Operating Profit After Tax) Pada PT. Gudang Garam, Tbk yang tercatat di Bursa Efek Indonesia Periode 2009-2014.

Nilai NOPAT PT. Gudang Garam, Tbk yang terdaftar di Bursa Efek Indonesia periode 2009-2014, menunjukkan bahwa NOPAT pada tahun 2009 adalah sebesar Rp 3.476.313 dan pada tahun 2010 NOPAT mengalami peningkatan sebesar Rp 747.159 sehingga menjadi Rp 4.223.472. Begitu pula di tahun 2011 NOPAT mengalami peningkatan sebesar Rp 737.756 menjadi Rp 4.961.228. Peningkatan ini disebabkan karena terjadinya peningkatan EBIT (Earning Before Interest Tax).

Pada tahun 2012 NOPAT mengalami penurunan sebesar Rp 813.243 sehingga menjadi Rp 4.147.985. Penurunan NOPAT ini disebabkan karena adanya penurunan EBIT. Kemudian pada tahun 2013 NOPAT mengalami peningkatan sebesar Rp300.000 menjadi Rp 4.447.985, begitu pula pada tahun 2014 dimana NOPAT mengalami peningkatan sebesar Rp 956.399 menjadi Rp 5.404.384.

b. WACC (Weight Average Cost Of Capital) Pada

PT. Gudang Garam, Tbk yang tercatat di Bursa Efek Indonesia Periode 2009-2014

Berdasarkan perhitungan WACC diperoleh hasil bahwa WACC pada tahun 2009 sebesar 15\% WACC tahun 2010 tidak mengalami peningkatan dimana tahun 2010 WACC sebesar $15 \%$. WACC tahun 2011 mengalami penurunan sebesar-1\% sehingga menjadi 14\%. Pada tahun 2012 WACC juga mengalami penurunan sebesar $-3 \%$ sehingga menjadi $11 \%$, Penurunan ini diakibatkan adanya penrunan biaya hutang. Pada tahun 2013 WACC sebesar $11 \%$ dengan kata laintidak mengalami peningkatan maupun penurunan. Pada tahun 2014
WACC mengalami peningkatan sebesar $1 \%$ sehingga menjadi $12 \%$, hal ini disebabkan karena terjadinya peningkatan biaya ekuitas.

\section{c. Invested Capital/ Modal yang diinvestasikan \\ Pada PT. Gudang Garam, Tbk yang tercatat di Bursa Efek Indonesia Periode 2009-2014.}

Berdasarkan perhitungan nilai IC (Invested Capital) pada tahun 2009 sebesar Rp 27.149.961 dan pada tahun 2010 IC mengalami peningkatan sebesar Rp 3.468.604 sehingga menjadi Rp 30.618.565. Pada tahun 2011 IC mengalami peningkatan sebesar Rp 8.470.140 sehingga menjadi Rp 39.088.705. Pada tahun 2012 IC mengalami peningkatan sebesar Rp 2.420.620 sehingga menjadi $\mathrm{Rp}$ 41.509.325. Kemudian Pada tahun 2013 IC mengalami peningkatan sebesar Rp 9.260.926 sehingga menjadi Rp 50.770.251. Begitu pula pada tahun 2014 IC mengalami peningkatan sebesar Rp 7.450.349 sehingga menjadi Rp 58.220.600.

Berdasarkan tabel 17, kita dapat melihat bahwa total modal yang diinvestasikan dari tahun 2009-2014 terus mengalami peningkatan. Hal ini disebabkan karena meningkatnya jumlah pinjaman maupun ekuitas pemegang saham. Kenaikan ekuitas pemegang saham disebabkan karena adanya laba ditahan perusahaan yang diperoleh dari dividen yang tidak dibagikan.

d. EVA (Economic Value Added) Pada PT. Gudang Garam, Tbk yang tercatat di Bursa Efek Indonesia Periode 2009-2014

Nilai EVA sebesar minus Rp 596.181. EVA tahun 2010 mengalami peningkatan sebesar Rp 226.868 menjadi minus Rp 369.313 kemudian tahun 2011 EVA juga mengalami penurunan sebesar minus Rp 141.878 sehingga menjadi minus Rp 511.191 hal ini disebabkan oleh tingginya biaya modal perusahaan dibandingkan nilai NOPAT. Kemudian pada tahun 2012-2014 EVA mengalami penurunan, dimana EVA tahun 2012 mengalami peningkatan sebesar Rp 93.150 sehingga menjadi minus $\mathrm{Rp}$ 418.041, peningkatan tersebut disebabkan oleh tingginya nilai NOPAT dibandingkan biaya modal.

Pada tahun 2013 menurun sebesar minus Rp 718.702 sehingga menjadi minus Rp 1.136.743 dan pada tahun 2014 EVA juga mengalami penurunan sebesar minus $\mathrm{Rp} 445.345$ menjadi minus Rp1.582.088. Hal ini disebabkan karena biaya modal lebih tinggi dari pada NOPAT sehingga nilai EVA negatif. Untuk mengurangi modal hutang, disarankan agar perusahaan mengeluarkan modal untuk menambah ekuitas.

Berdasarkan perhitungan nilai EVA dari Tahun 2009-2014 menunjukkan bahwa manajemen perusahaan belum mampu menciptakan nilai EVA yang baik karena setelah kita lihat data tahun 20122014, perusahaan belum mampu menciptakan nilai EVA yang stabil karena ditahun 2012-2014 EVA secara terus-menerus mengalami penurunan. 
e. Komparatif NOPAT, WACC, Invested Capital/ Modal yang diinvestasikan dan EVA Pada PT. Gudang Garam, Tbk yang tercatat di Bursa Efek Indonesia Periode 2009-2014.

Berdasarkan hasil analisis dapat dilihat bahwa NOPAT (Net Operating After Tax) secara linear dari tahun 2009-2014 meningkat tapi peningkatannya tidak terlalu tinggi hal ini disebabkan perolehan ebit juga tidak terlalu tinggi. WACC (rata-rata biaya modal tertimbang) dari tahun 2009-2014 cenderung menurun, WACC yang tertinggi pada tahun 2009 sebesar 15\% dan terendah pada tahun 2012 dan tahun 2013 sebesar 11\%, pada tahun 2014 WACC naik menjadi $12 \%$.

IC (Modal yang diinvestasikan) untuk operasional terdiri dari modal pinjaman dari tahun 2009-2014 meningkat. Nilai IC yang terendah pada tahun 2010 sebesar Rp 27.149.961 dan IC tertinggi pada tahun 2014 sebesar $\mathrm{Rp} 58.220 .600$, Peningkatan IC mengakibatkan biaya modal yang ditanggung perusahaan juga meningkat sehingga EVA perusahaan menurun, meskipun NOPAT meningkat.

EVA (Nilai tambah Ekonomi) tahun 20092014 menurun tajam dimana pada tahun 2010 nilai EVA sebesar minus Rp 369.313 dan nilai EVA tahun 2014 sebesar minus Rp 1.582.088. Hal ini karena biaya modal yang ditanggung perusahaan meningkat dari Rp 3.800.994 pada tahun 2009 meningkat menjadi Rp 6.986.472 pada tahun 2014. Maka dapat disimpulkan bahwa penurunan kinerja keuangan PT. Gudang Garam, Tbk disebabkan biaya modal yang ditanggung perusahaan cukup tinggi dibandingkan dengan perolehan NOPAT. Oleh karena itu, sebaiknya perusahaan mengurangi penggunaan biaya modal dengan mengurangi pinjaman (hutang).

\section{KESIMPULAN DAN SARAN}

\section{Kesimpulan}

a. Nilai NOPAT mengalami fluktuasi yang diakibatkan peningkatan dan penurunan nilai EBIT (Earning Before Interest Tax).

b. Dari tahun 2009-2014 PT. Gudang Garam, Tbk belum juga berhasil menurunkan biaya modal rata-rata tertimbang (WACC).Hal ini akan sangat menghalangi perusahaan untuk mendapatkan nilai EVA yang positif sehingga tidak dapat memberikan nilai tambah ekonomis bagi perusahaan.

c. Berdasarkan perhitungan EVA tahun 2009-2014 menunjukkan bahwa manajemen perusahaan belum mampu menciptakan nilai EVA yang positif yang artinya perusahaan belum dapat menciptakan nilai tambah kekayaan perusahaan. Hal ini disebabkan karena biaya modal lebih tinggi dari pada NOPAT sehingga nilai EVA negatif. Maka dapat dikatakan kinerja perusahaan tersebut buruk.

\section{Saran}

a. Dalam meningkatkan EVA, sebaiknya perusahaan mengurangi penggunaan biaya modal dengan mengurangi pinjaman (hutang). b. Dalam pengaplikasian EVA sebaiknya pihak managemen memonitori atau mengevaluasi atas kewajaran tingkat biaya modal yang digunakan dalam sebuah operasi usaha.

c. Mengingat keterbatasan penulis, untuk itu bagi peneliti selanjutnya agar meneruskan dan melengkapi kekurangan-kekurangan dalam penelitian ini dengan variabel yang sama atau variabel lainnya dalam meningkatkan kinerja keuangan.

\section{E. DAFTAR PUSTAKA}

Anthony, Robert N and Vijay Govindarajan. 2005. Sistem Pengendalian Manajemen. Jakarta: Salemba Empat.

Baridwan. 2004.Metode dan Teknik Menyusun Analisis Data. Cetakan Pertama,Bandung: Alfabeta.

Brealey, Richard A, Stewart C.Mayers, dan Alan J.Marcus. 2007. Dasar-dasar Manajemen Keuangan Perusahaan. Jilid 2. Edisi Kelima. Jakarta: Erlangga.

Brigham, Eugene F and Joel F Houston. 2006. Dasar-dasar Manajemen Keuangan, alih bahasa Ali Akbar Yulianto. Buku 1, Edisi sepuluh, Jakarta: Salemba Empat.

-.2012. Dasar-dasar Manajemen Keuangan. Buku 1, Edisi sebelas, Jakarta: Salemba Empat.

HorneVan, James C, Jhon M.Wachowicz, jr. 2013. Prinsip-Prinsip Manajemen Keuangan. Jakarta: Salemba Empat.

Jumingan. 2006. Analisis Laporan Keuangan. Buku Ketiga, Jakarta : Salemba Empat.

Martani, Dwi, dkk. 2012. Akuntansi Keuangan Menengah Berbasis PSAK. Jakarta: Salemba Empat.

Munawir, Slamet. 2004. Analisa Laporan Keuangan. Yogyakarta: Liberty Yogyakart 
